\title{
DAMPAK STRUKTUR KEPEMILIKAN TERHADAP KEPUTUSAN PENDANAAN PADA PERUSAHAAN MANUFAKTUR (Suatu Penelitian Eksperimen)
}

\author{
Mappa Panglima Banding ${ }^{1)}$, Hasnawati ${ }^{2)}$ \\ (Universitas Bornepo Tarakan)
}

\begin{abstract}
Abstrak: Penelitian ini bertujuan untuk mengkaji dan memperoleh bukti empiris dari dampak struktur kepemilikan terhadap keputusan pendanaanpada perusahaan manufaktur. Jenis penelitian ini adalah eksperimen laboratorium dengan mengunakan completely randomized designs $(C R-p)$. Dimana sampelnya adalah randomized partisipan (partisipan acak) sebanyak 20 orang berdasarkan kategori yang telah ditentukan sebelumnya dan dibagi menjadi dua kelompok yang menjadi pengambil keputusan yang propesional. Partisipan diperhadapkan dengan dua treatment manipulasi. Berdasarkan analisis data ANOVA peneliti memperoleh hasil bahwa data yang diambil adalah efektif. Dari teknik analisis data yang digunakan untuk menguji hipotesis adalah Repeated Measures $t$ Test menggunakan sofware SPSS 23,0 dengan data berupa hasil pengisian foam simulasi pembuatan keputusan pendanaan. Dan dari hasil pengujian diperoleh bahwa kinerja keuangan berimplikasi terhadap keputusan pendanaan.
\end{abstract}

\section{Kata kunci: Struktur Kepemilikan, Keputusan Pendanaan dan ANOVA}

Abstrack: This study aimed to examine and obtain empirical evidence ofthe impact of ownership structure on funding decisions on manufacturing companies. The research is a laboratory experiment by using completely randomized designs $(C R-p)$. Where the sample was randomized participants (participants randomized) of 20 people based on categories that are predefined and are divided into two groups into the decision-making professionals. Participants are confronted with two manipulation treatment. Based on data analysis ANOVA researchers obtained results that data collected is effective. From the data analysis technique used to test the hypothesis is Repeated Measures t test using SPSS 23.0 software with data such as the results of the simulation foam filling the funding decision-making.

Keywords: Ownership Structure, Funding Decisions and ANOVA

\section{LATAR BELAKANG}

Salah satu keputusan penting yang harus dilakukan oleh seorang manajer khususnya manajer keuangan dalam kaitannya dengan kelangsungan dan pengembangan operasi perusahaan adalah keputusan pendanaan atau keputusan struktur modal. Bagaimana perusahaan memperoleh dana untuk memenuhi kebutuhan investasinya, bagaimana komposisi dari modal sendiri dan hutang, serta bagaimana hutang yang akan digunakan tersebut apakah jangka panjang atau mungkin jangka pendek. Sebagai seorang manajer harus mampu menghimpun dana baik dana tersebut berasal dari dalam perusahaan atau bahkan berasal dari luar perusahaan secara efisien dan efektif.

Setiap perusahaan membutuhkan modal yang akan digunakan untuk melaksanakan kegiatannya, baik itu untuk memenuhi kebutuhan investasi jangka panjang maupun kegiatan operasional seharihari pada suatu perusahaan. Karena modal merupakan alat yang sangat penting bagi perusahaan dalam kelancaran kegiatan operasionalnya. Jumlah modal yang dibutuhkan pada suatu perusahaan akan berbeda sesuai dengan besar kecilnya 
perusahaan. Semakin besar perusahaan, maka dana yang dibutuhkan juga semakin banyak. Sebaliknya semakin kecil perusahaan, maka dana yang dibutuhkan tentunya juga akan semakin sedikit.

Terdapat dua sumber pembiayaan yang dapat digunakan oleh perusahaan untuk menjalankan kegiatan operasinya, pertama ada sumber pembiayaan yang berasal dari dalam perusahaan itu sendiri (internal financing) seperti modal sendiri yang berasal dari pemiliknya dan laba ditahan (retained earning). Kedua ada sumber pembiayaan yang berasal dari luar perusahaan (external financing) seperti hutang atau dengan cara menerbitkan saham dan obligasi.

Selain dari kebijakan pendanaan, seorang manajer juga harus memperhatikan kebijakan lainnya, seperti kebijakan investasi, kebijakan dividend dan struktur kepemilikan pada suatu perusahaan.Di mana keempat kebijakan tersebut memiliki keterkaitan atau hubungan antara yang satu dengan yang lainnya dalam mencapai tujuan perusahaan.Tujuan utama perusahaan yaitu meningkatkan nilai perusahaan melalui peningkatan kemakmuran pemilik atau para pemegang saham.

Penelitian yang dilakukan oleh 1 menghasilkan bahwa struktur kepemilikan (managerial dan institutional ownership) berpengaruh positif terhadap Debt to Equity Ratio (DER), artinya semakin besar proporsi kepemilikan saham oleh manajerial maka akan meningkatkan hutang perusahaan. Hal ini menunjukkan bahwa para pemilik baik managerialmaupun institutional lebih memilih sumber pendanaan dari luar perusahaan walaupun memiliki risiko yang tinggi.

Dari keterangan di atas secara jelas menyatakan bahwa karakteristik umum pada suatu struktur kepemilikan perusahaan dapat mempengaruhi pencapaian tujuan perusahaan.Sehingga struktur kepemilikan perusahaan dapat mempengaruhi keputusan keuangan.Sehingga, dengan demikian penting untuk dilakukannya sebuah penelitian mengenai dampak struktur kepemilikan terhadap keputusan pendanaan.

\section{RUMUSAN MASALAH}

Berdasarkan pada latar belakang yang telah dipaparkan diatas terkait dengan dampak struktur kepemilikan terhadap keputusan pendanaan, maka rumusan permasalahan penelitian ini yaitu "Apakah struktur kepemilikan berdampak pada keputusan pendanaan?".

\section{TUJUAN PENELITIAN}

Sesuai dengan perumusan masalah yang telah diuraikan, maka tujuan dari penelitian ini adalah untuk mengetahui dampak struktur kepemilikan terhadap keputusan pendanaan

\section{TINJAUAN PUSTAKA}

\section{$\underline{\text { Struktur Kepemilikan Saham }}$}

Pengelolaan perusahaan yang semakin dipisahkan dari kepemilikan perusahaan merupakan salah satu ciri perekonomian modern, hal ini sesuai dengan agency theory yang menginginkan pemilik perusahaan (principal) menyerahkan pengelolaan perusahaan kepada tenaga professional (agent) yang lebih mengerti dalam menjalankan bisnis. Tujuan dipisahkannya pengelolaan dan kepemilikan perusahaan yaitu agar pemilik memperoleh keuntungan maksimal dengan biaya yang efesien.

Keberhasilan penerapan corporate governance tidak terlepas dari struktur kepemilikan perusahaan. Struktur kepemilikan tercermin baik melalui instrument saham maupun instrument utang sehingga melalui struktur tersebut dapat ditelaah kenungkinan bentuk masalah keagenan yang akan terjadi ${ }^{2}$. Ada beberapa hal yang perlu diperharikan dalam struktur kepemilikan antara lain:

1. Kepemilikan sebagian kecil perusahaan oleh manajemen mempengaruhi kecenderungan untuk memaksimalkan nilai pemegang saham dibanding sekedar mencapai tujuan perusahaan semata. 
2. Kepemilikan yang terkonsentrasi memberi insentif kepada pemegang saham mayoritas untuk berpartisipasi secara aktif dalam perusahaan.

3. Identitas pemilik menentukan prioritas tujuan sosial perusahaan dan maksimalisasi nilai pemegang saham, misalnya perusahaan milik pemerintah cenderung untuk mengikuti tujuan politik dibanding tujuan perusahaan.

Menurut masalah keagenan timbul karena adanya benturan keinginan antara pemilik perusahaan (pemegang saham mayoritas) dengan manajer pengelola.Oleh karena itu, struktur kepemilikan dianggap sebagai hal yang krusial untuk mengatasi masalah keagenan karena dengan struktur kepemilikan yang baik terwujud suatu kinerja perusahaan yang layak karena manajer sebagai pihak yang berkompeten dalam pengelolaan perusahaan yang mempunyai wewenang cukup untuk menjalankan tugasnya Ittuiraga \& Saz (1998) dalam Carolina (2007).

\section{$\underline{\text { Kepemilikan Saham Manajerial }}$}

Kepemilikan saham manajerial adalah proporsi saham biasa yang dimiliki oleh para manajemen, yang dapat diukur dari presentasi saham biasa yang dimiliki oleh pihak manajemen yang secara aktif terlibat dalam pengambilan keputusan perusahaan 3 . Menurut 4 dalam 3, kepemilikan manajer akan saham perusahaan dipandang dapat menyelaraskan potensi perbedaan kepentingan antara pemegang saham diluar manajemen sehingga permasalahan keagenan diasumsikan akan hilang apabila seorang manajer adalah juga sebagai seorang pemilik.

$$
\text { Kepemilikan Manajerial }=\frac{\begin{array}{c}
\text { Saham Yang Dimiliki Manajemen, } \\
\text { Direksi dan Komisaris }
\end{array}}{\text { Jumlah Saham Yang Beredar }} \text { X 100\% }
$$

\section{$\underline{\text { Kepemilikan Saham Institusional }}$}

Kepemilikan saham institusional adalah kepemilikan saham oleh pemerintah, institusi keuangan, institusi berbadan hukum, institusi luar negeri, dan perwalian serta institusi lainnya pada akhir tahun (Shien dkk, 2006).

$$
\text { Kepemilikan Manajerial= } \frac{\begin{array}{c}
\text { Saham Yang Dimiliki Manajemen, } \\
\text { Direksi dan Komisaris }
\end{array}}{\text { Jumlah Saham Yang Beredar }} \text { X 100\% }
$$

Keputusan Pendanaan

Keputusan pendanaan merupakan keputusan mengenai sumber dana yang digunakan oleh perusahaan dimana sumber dana tersebut terbagi dua sumber yaitu sumber dana internal dan sumber dan eksternal 6. Keputusan pendanaan dapat pula diartikan sebagi keputusan yang menyangkut struktur keuangan perusahaan. Dimana struktur keuangan perusahaan merupakan komposisi dari keputusan pendanaan yang meliputi hutang jangka pendek, hutang jangka panjang, dan modal perusahaan). Adanya investasi yang dilakukan perusahaan mengakibatkn perubahan dalam struktur keuangan, oleh sebab itu besar kecinya investasi yang dilakukan perusahaan akan mempengaruhi komposisi struktur pendanaan.

Dalam beberapa penelitian sebelumnya seperti ${ }^{1}$ melakukan penelitian tentang pengaruh struktur kepemilikan terhadap keputusan pendanaan. Penelitian ini menggunakan model dimana variabel dependennya adalah keputusan pendanaan dan variabel independennya adalah struktur kepemilikan. Dengan hasil yang menyatakan bahwa Debt to Equity Ratio (DER), Managerial Ownership, Institutional Ownership dan Dividend Payout Ratio (DPR) berpengaruh terhadap Debt to Equity Ratio (DER).

Melakukan penelitian yang bertujuan untuk mengevaluasi pengaruh struktur kepemilikan terhadap profitabilitas perusahaan manufaktur yang terdaftar di Bursa Efek Indonesia (BEI). Hasil pengujian menunjukkan bahwa kepemilikan asing dan leverage berpengaruh positif terhadap profitabilitas perusahaan.

Melakukan penelitian yang bertujuan untuk meneliti pengaruh struktur kepemilikan saham dalam perusahaan 
sebagai dimensi dari mekanisme corporate governance terhadap peningkatan kinerja perusahaan.Hasil dari penelitian ini menunjukkan bahwa kepemilikan institusional dan kepemilikan asing dalam perusahaan memiliki pengaruh yang positif dan signifikan terhadap kinerja perusahaan.Sedangkan kepemilikan manajerial dan kepemilikan publik tidak berpengaruh terhadap kinerja perusahaan.

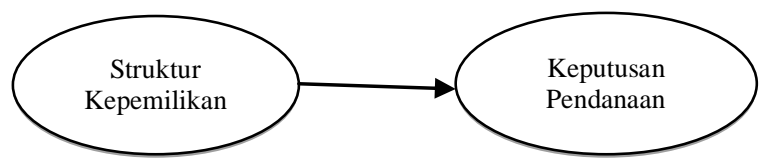

Ha: Struktur kepemilikan berdampak positif terhadap keputusan pendanaan

\section{METODOLOGI PENELITIAN}

\section{Desain Dasar Eksperimen}

Penelitian ini merupakan jenis penelitian eksperimen dasar desain completely randomized yaitu desain yang secara simultan mengakomodasi penelitian atas pengaruh satu variabel independen terhadap variabel dependen.
$\mathrm{R} \quad \mathrm{X}$
$\mathrm{O} 1$
$\mathrm{R}$
$\mathrm{O} 2$

Dimana : $\mathrm{R}$ adalah randomisasi

$\mathrm{X}$ adalah manipulasi

$\mathrm{O}$ adalah observasi

$\underline{\text { Manipulasi }}$

Dalam hal ini peneliti memiliki kendali atau kontrol penuh untuk memanipulasi variabel independen. Manipulasi ini dilakukan dalam bentuk pemberian perlakuan (treatment) yang berbeda pada kelompok-kelompok subjek yang berbeda yang berbeda pada kelompok-kelompok subjek yang semula kondisinya setara, dan juga berupa pengendalian agar variabelvariabel yang tidak relevan dapat disingkirkan pengaruhnya dari eksperimen. Jadi setiap gejala yang terjadi pada variabel dependen dapat dikembalikan penyebabnya pada perbedaan perlakuan yang diberikan (Saifudin Azwar, 2007:108).

\section{Desain Dasar Manipulasi terhadap Objek}

Untuk menguji intraktif antar grup dan penggunaan eksperimen laboraturium yaitu kegiatan yang dilakukan artifisial dan berpisah dari kegiatan sehari-hari partisipan maka desain yang paling tepat digunkan dalam penelitian ini adalah desain dasar eksperimen dengan grup kontrol dan purnauji atau posttest control grup desing ${ }^{8}$.

Posttest control group design merupakan desain yang terdapat dua kelompok yang masing-masing dipilih secara random (R). Grup pertama diberikan perlakuan (X) dan grup yag lain tidak. Kelompok yang diberikan perlakuan (treatment) disebut kelompok eksperimen, sedangkan kelompok yang tidak diberikan perlakuan (treatment) disebut kelompok kontrol. Pada kelompok eksperimen, terdapat 1 (satu) variabel independen dengan memiliki dua level, yaitu:

(X) Struktur Kepemilikan

1. Mayoritas struktur kepemilikan institusional dan Minoritas struktur kepemilikan manajerial

2. Mayoritas struktur kepemilikan manajerial dan Minoritas struktur kepemilikan instutisional

Desain ini dapat disimbolkan sebagai berikut:
$\mathrm{R} \quad \mathrm{X}$
$\mathrm{O} 1$
(Grup Experimen )
$\mathrm{R}$
$\mathrm{O} 2$
(Grup Kontrol )

Sehingga dalam eksperimen ini manipulasi dari objek dapat disimpulkan sebagai berikut

1. Dalam kondisi pengungkapan pertama, objek yang dimanipulasi adalah data struktur kepemilikan, data struktur kepemilikan mayoritas kepemilikan institusional dan kepemilikan manajerial.

2. Dalam kondisi pengungkapan kedua, objek yang dimanipulasi adalah data struktur kepemilikan, data struktur kepemilikan mayoritas kepemilikan 
manajerial dan minoritas kepemilikan institusional.

Desain Dasar Manipulasi terhadap Subjek

Dalam eksperimen ini yang menjadi subjek eksperimen yaitu para manajer atau pengambil keputusan dalam sebuah perusahaan yang menerima semua manipulasi dari objek yang diteliti, artinya terjadi pengukuran berulang terhadap masing-masing subjek untuk semua kondisi manipulasi terhadap objek sehingga desain ini biasa juga disbut desain pengukuran berulang atau desain intrasubjek.

\section{Uji Manipulasi (Pilot Study dan Manipulasi)}

Sebelum diaplikasikan dalam eksperimen yang sesungguhnya, desain manipulasi harus terlebih dahulu dilakukan pengecekan untuk mendapatkan keyakinan bahwa subjek sudah menerima manipulasi dengan takaran dan bentuk yang sudah dirancang oleh peneliti.

Subjek Eksperimen, Kelompok Subjek Termanipulasi dan Subjek Pembanding (Kontrol Grup)

Untuk penelitian eksperimen yang sederhana dengan pengendalian yang ketat, ukuran sampel bisa antara $10 \mathrm{~s} / \mathrm{d} 20$ elemen (Rescoe, 1975) dikutip dari ${ }^{11}$. Penelitian ini mempergunakan desain eksperimen intrasubjek (within subject) maka sampel atau partisipan yang dibutuhkan hanya setengah dari partisipan untuk mendapatkan nilai yang sama untuk setiap manipulasi seperti halnya pada desain antarsubjek atau between subject (Ghozali, 2008), sehingga jumlah subjek atau partisipan pada penelitian ini adalah 10 partisipan yang dihitungdengan cara sebagaiberikut:

$$
\text { Partisipan (n) }=\frac{\text { Jumlah Manipulasi x } 10}{2}
$$

Rencana Waktu dan Tempat Pelaksanaan Eksperimen

Dalam metode eksperimen, akan dilakukan manipulasi terhadap variabel independen yaitu struktur kepemilikan. Metode eksperimen ini dilakukan pada tempat yang berbeda dengan waktu penelitian pada tanggal 25 Mei hingga 06 Juni 2018. Adapun tempat penelitian, dapat dilihat pada table berikut:

Tabel 1. Tempat Simulasi

\begin{tabular}{|c|c|c|c|}
\hline No. & Instansi & Tempat & $\begin{array}{c}\text { Jumlah } \\
\text { Partisipan }\end{array}$ \\
\hline 1. & $\begin{array}{l}\text { Fakultas } \\
\text { Ekonomi, } \\
\text { Universitas } \\
\text { Borneo } \\
\text { Tarakan }\end{array}$ & $\begin{array}{l}\text { Ruang } \\
\text { Dosen }\end{array}$ & 3 Orang \\
\hline 2. & BAPPEDA & $\begin{array}{c}\text { Ruang } \\
\text { Kerja }\end{array}$ & 3 Orang \\
\hline 3. & $\begin{array}{l}\text { Sekretariat } \\
\text { Daerah Kota } \\
\text { Tarakan }\end{array}$ & $\begin{array}{c}\text { Ruang } \\
\text { Kerja }\end{array}$ & 2 Orang \\
\hline 4. & Hotel Paradise & $\begin{array}{c}\text { Ruang } \\
\text { Kerja }\end{array}$ & 1 Orang \\
\hline 5. & Hotel Kaisar & $\begin{array}{c}\text { Ruang } \\
\text { Kerja }\end{array}$ & 1 Orang \\
\hline
\end{tabular}

Definisi Operasional dan Pengukuran Variabel Eksperimen

\section{Definisi Operasional}

Variabel independen adalah variabel yang nilainya menentukan variabel lain dan biasanya pada variabel ini dimanipulasi, diamati, dan diukur untuk diketahui hubungannya atau pengaruhnya terhadap variabel lain (Nursalam, 2008). Dalam penelitian ini variabel independennya adalah struktur kepemilikan dimana variabel ini ukuran indikatorrnya adalah mayoritas struktur kepemilikan instutisional dan 
minoritas struktur kepemilikan manajerial dan mayoritas struktur kepemilikan manajerial dan minoritas struktur kepemilikan instutisional yang disajikan oleh perusahaan.

Pengukuran Variabel Eksperimen

Dalam pengukuran variabel eksperimen dapat dilihat pada tabel berikut:

Tabel 2.Variabel, Jenis Data dan Skala Pengukuran

\begin{tabular}{|c|c|c|}
\hline Variabel & Jenis Data & $\begin{array}{c}\text { Skala } \\
\text { Pengukur } \\
\text { an }\end{array}$ \\
\hline $\begin{array}{l}\text { Struktur } \\
\text { Kepemilik } \\
\text { an }(\mathrm{X})\end{array}$ & \begin{tabular}{|l}
\multicolumn{1}{|c}{ Metrik: } \\
1. \\
Menerima data \\
struktur \\
kepemilikan \\
dengan \\
mayoritas \\
kepemilikan \\
institusional \\
dan minoritas \\
kepemilikan \\
manajerial. \\
2. \\
Menerima data \\
struktur \\
kepemilikan \\
dengan \\
mayoritas \\
kepemilikan \\
manajerial dan \\
minoritas \\
kepemilikan \\
institusional.
\end{tabular} & $\begin{array}{c}\text { Nominal: } \\
1-2\end{array}$ \\
\hline $\begin{array}{l}\text { Keputusan } \\
\text { Pendanaan } \\
\text { (Y) }\end{array}$ & $\begin{array}{c}\text { Metrik: } \\
\text { Jumlah } \\
\text { keputusan } \\
\text { pendanaan yang } \\
\text { diberikan }\end{array}$ & $\begin{array}{c}\text { Rasio: } \\
\text { Tidak } \\
\text { membeli } \\
\text { atau nol } \\
\text { (0) s.d } 10 \\
\text { lot per } \\
\text { saham }\end{array}$ \\
\hline
\end{tabular}

$\underline{\text { Model Analisis Data }}$

$\underline{\text { Model Matematis }}$

Uji Chi-Square

Uji Chi-Square bertujuan untuk mengetahui hubungan antara variabel yang terdapat pada baris dan kolom. Adapun dasar pengambilan keputusan, yaitu:

1. Jika nilai Asimp. Sig $<0.05$, maka terdapat hubungan yang signifikan antara baris dengan kolom.

2. Jika nilai Asimp. Sig $\geq 0.05$, maka tidak terdapat hubungan yang signifikan antara baris dengan kolom.

Uji Normalitas Shapiro-Wilk

Uji Normalitas bertujuan untuk mengetahui apakah data penelitian untuk variabel berdistribusi normal apa tidak. Dalam hal ini untuk menguji normalitas dengan Shapiro-Wilk dengan dasar pengambilan keputusan sebagai berikut:

1. Jika nilai $\mathrm{Sig} \geq 0.05$, maka data berdistribusi normal.

2. Jika nilai Sig $<0.05$, maka data tidak berdistribusi normal.

\section{Uji Homogeneity}

Uji Homogeneity adalah pengujian mengenai sama tidaknya variansi-variansi dua buah distribusi atau lebih. Adapun dasar pengambilan keputusan sebagai berikut:

1. Jika nilai Signifikansi $\geq 0.05$, maka distribusi adalah homogen.

2. Jika nilai Asimp. Sig $<0.05$, maka distribusi data adalah tidak homogen.

Uji Analysis of Variance (ANOVA)

Uji Analysis of Variance (ANOVA) adalah pengujian yang dilakukan untuk melihat ada tidaknya perbedaan. Uji ini dilakukan apabila terlihat hasil dari uji Shapiro-Wilk berdistribusi normal dan hasil uji Homogeneity berdistribusi homogen dengan dasar pengambilan keputusan sebagai berikut:

1. Jika nilai probabilitas signifikansi $\geq 0.05$ maka tidak terdapat perbedaan yang signifikan keputusan pendanaan yang dilakukan dengan menggunakan 2 (dua) perlakuan(treatment) data struktur kepemilikan. 
2. Jika nilai probabilitas signifikansi $<0.05$ maka terdapat perbedaan yang signifikan keputusan pendanaan yang dilakukan dengan menggunakan 2 (dua) perlakuan(treatment) data struktur kepemilikan.

\section{$\underline{\text { Uji Hipotesis }}$}

Untuk model matematis dari design Completely Randomized CR-p dapat ditulis sebagai berikut:

$$
\begin{gathered}
Y i j=\mu+\alpha j+\varepsilon i(j)(i=1, \ldots \ldots \ldots \ldots \ldots \ldots n ; j= \\
1, \ldots \ldots \ldots \ldots . ., p)
\end{gathered}
$$

Dimana :

$$
\text { Yij : pengaruhstruktur kepemilikan }
$$
ke-i dengan treatmen level $a j$

$\mu \quad$ : grand mean dari 2 grup mean keputusan pendanaan

aj : pengaruh treatmen untuk populasi $\alpha \mathrm{j}$ dan besarnya sama dengan $\quad \mu j-\mu$,mencerminkan pengaruh struktur kepemilikan $\alpha j$

cij : pengaruh kesalahan within group yang berhubungan dengan $Y i j$ dansama dengan $Y i j-\mu-\alpha j$. Hal ini mencerminkan semua pengaruh yang dapatdikaitkan dengan level $\alpha \mathrm{j}$

Dengan desain CR-p maka hipotesis yang dapat diuji adalah sebagai berikut:

$\mathrm{H}_{0} \quad: \mu 1 .=(\mu 1=\mu 2)=0$ (tidak ada perbedaan rata-rata struktur kepemilikan)

$\mathrm{H}_{\mathrm{a}} \quad: \mu 1-\mu 2 \neq 0$ (ada perbedaan ratarata struktur kepemilikan)

Dengan kriteria struktur kepemilikan:

1. Jika angka Sig < 0.05 maka Ha diterima dan H0 ditolak, yang artinya terdapat dampak struktur kepemilikan terhadap keputusan pendanaan.

2. Jika angka Sig. $\geq 0.05$ maka H0 diterima dan Ha ditolak, yang artinya tidak terdapat dampak antara struktur kepemikan dengan keputusan pendanaan

\section{HASIL PENELITIAN}

\section{Uji Manipulasi}

Uji manipulasi pertama dilakukan secara online pada tanggal 03-30 April 2018 dengan jumlah partisipan 8 orang, kemudian untuk menggenapkan jumlah partisipan uji manipulasi pertama dilakukannya penyebaran simulasi secara offline pada tanggal 08 Mei 2018 dengan jumlah partisipan sebanyak 2 orang. Uji manipulasi kedua dilakukan secara offline pada tanggal 09-24 Mei 2018 dengan jumlah partisipan 10 orang.Kemudian yang terakhir eksperimen dilakukan secara offline pada tanggal $25 \mathrm{Mei}$ 2018 hingga 06 Juni 2018.

\section{$\underline{\text { Karakteristik Subjek Beserta Uji Manipulasi }}$}

Subjek partisipan uji maipulasi yang dipilih adalah praktisi pengambilan keputusan dimana yang dproksikan sebagai manajer keuangan atau pengambil keputusan yaitu orang-orang yang berpendidikan Strata 1 (S1), Strata 2 (S2) dan Strata 3 (3), latar belakang pendidikan ekonomi dan yang bukan ekonomi tetapi dalam kedudukan perkerjaannya dari bagian keuangan, dan memahami perannya sebagai pengambil keputusan. Adapun rincian karakteristik subjek manipulasi dapat dilihat pada tabel di bawah ini:

Tabel 3.

Karakteristik Subjek Manipulasi

\begin{tabular}{|l|l|c|c|}
\hline No. & Karakteristik & Frekuensi & $\begin{array}{c}\text { Persentase } \\
(\%)\end{array}$ \\
\hline 1. & Jenis Kelamin: & & $70 \%$ \\
& $\begin{array}{l}\text { a. Pria } \\
\text { b. Wanita }\end{array}$ & 3 & $30 \%$ \\
\hline \multicolumn{2}{|c|}{ Total Partisipan } & $\mathbf{1 0}$ & $\mathbf{1 0 0 \%}$ \\
\hline
\end{tabular}


Tabel 3.

Karakteristik Subjek Manipulasi

(Lanjutan)

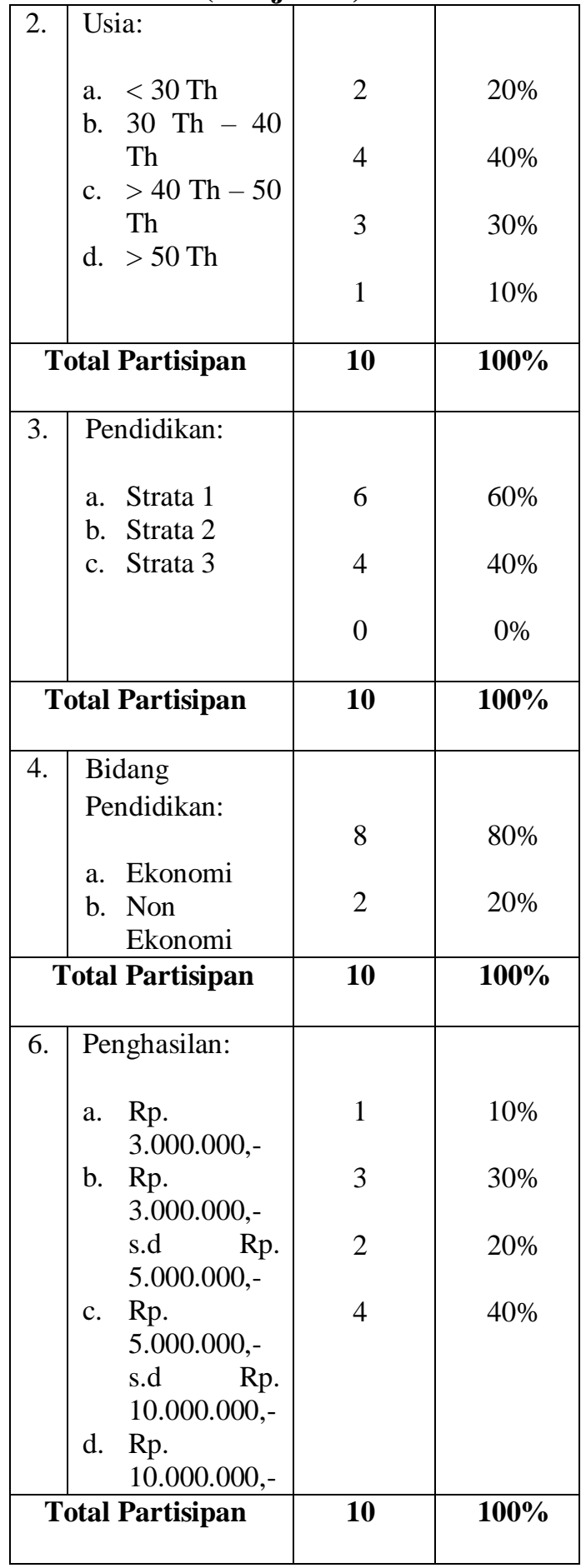

Tabel 3.

Karakteristik Subjek Manipulasi

(Lanjutan)

\begin{tabular}{|l|l|c|c|}
\hline 7. & Institusi: & & \\
a. & $\begin{array}{l}\text { BUMN / } \\
\text { BUMD }\end{array}$ & 3 & $30 \%$ \\
b. $\begin{array}{l}\text { Perusahaan } \\
\text { Swasta } \\
\text { Lainnya } \\
\text { c. } \begin{array}{l}\text { Pendidikan } \\
\text { Tinggi }\end{array}\end{array}$ & 5 & $50 \%$ \\
\hline \multicolumn{2}{|c|}{ Total Partisipan } & $\mathbf{1 0}$ & $\mathbf{1 0 0 \%}$ \\
\hline
\end{tabular}

Sumber: Data Diolah

Dari deskripsi di atas maka dapat disimpulkan bahwa dari 10 partisipan ialah mayoritas berjenis kelamin pria atau sekitar $70 \%$, dari segi usia mayoritas sekitar 30 hingga 40 tahun atau sekitar $40 \%$, dari segi pendidikan mayoritas berasal dari tamatan Strata 1 (S1) atau sekitar $60 \%$, dari segi bidang pendidikan mayoritas berasal dari bidang ekonomi atau sekitar 80\%, dari segi penghasilan setiap bulannya mayoritas sebesar Rp. 10.000.000,-, dan dari segi asal institusi mayoritas berasal dari perusahaan swasta lainnya atau sekitar 50\%.

\section{$\underline{\text { Uji Randomisasi }}$}

Randomisasi bertujuan untuk mengurangi atau menghilangkan bias yang terjadi akibat perbedaan karateristik subjek (Nahartyo \& Utami, 2016). Tujuan dari randomisasi itu sendiri adalah untuk memastikan bahwa telah dilakukan randomisasi dengan benar terhadap partisipan atau subjek dalam eksperimen.Untuk memastikan bahwa randomisasi telah dilakukan dengan benar makan dilakukan Chi-Square tes, Uji Normalitas Shapiro-Wilk, dan Analysis of Variance (ANOVA). Secara ringkas dapat digambarkan dengan tabel sebagai berikut:

Tabel 4.

Uji Randomisasi

\begin{tabular}{|c|l|l|}
\hline Jenis Uji & $\begin{array}{c}\text { Hasil } \\
\text { Uji }\end{array}$ & \multicolumn{1}{|c|}{ Kesimpulan } \\
\hline $\begin{array}{c}\text { Chi- } \\
\text { Square }\end{array}$ & $\begin{array}{l}\text { Rata- } \\
\text { rata } \\
\text { nilai } \\
\text { Asymp. } \\
\text { Sig. } \geq \\
0.05\end{array}$ & $\begin{array}{l}\text { Tidak } \\
\text { hubunganyang } \\
\text { berbedaantarmanipulasi } \\
\text { atausel(sepadan). }\end{array}$ \\
\hline
\end{tabular}


Uji Chi-Square

Tabel 5.

Uji Chi-Square

\begin{tabular}{|c|c|c|c|c|c|c|}
\hline \multicolumn{7}{|c|}{ Test Statistics } \\
\hline & $\begin{array}{c}\text { Jenis } \\
\text { Kelam } \\
\text { in }\end{array}$ & Usia & \begin{tabular}{|c} 
Strata \\
Pendid \\
ikan
\end{tabular} & $\begin{array}{c}\text { Latar } \\
\text { Belakang } \\
\text { Pendidikan }\end{array}$ & $\begin{array}{c}\text { Peng } \\
\text { hasilan }\end{array}$ & $\begin{array}{c}\text { Institu } \\
\text { si }\end{array}$ \\
\hline $\begin{array}{l}\text { Chi- } \\
\text { Squa } \\
\text { re }\end{array}$ & $3.200^{\mathrm{a}}$ & $7.600^{\mathrm{b}}$ & $12.400^{\mathrm{b}}$ & $.800^{\mathrm{a}}$ & $2.800^{\mathrm{b}}$ & $1.600^{\mathrm{b}}$ \\
\hline Df & 1 & 2 & 2 & 1 & 2 & 2 \\
\hline $\begin{array}{l}\text { Asy } \\
\text { mp. } \\
\text { Sig. }\end{array}$ & .074 & .022 & .002 & .371 & .247 & .449 \\
\hline
\end{tabular}

Sumber: Data Olahan SPSS

Berdasarkan tabel 5 diketahui bahwa asymp signifikansi sebesar 0,074 untuk jenis kelamin, 0,371 untuk latar belakang pendidikan, 0,247 untuk penghasilan, dan 0,449 untuk institusi atau dengan kata lain nilai jenis kelamin, latar belakang pendidikan, penghasilan dan institusi $\geq 0,05$ artinya tidak terdapat hubunganyang berbedaantarmanipulasi atausel(sepadan).

\section{Uji Normalitas Shapiro-Wilk}

Tabel 6.

Uji Normalitas Shapiro-Wilk

\begin{tabular}{|c|c|c|c|c|c|c|}
\hline \multicolumn{7}{|c|}{ Tests of Normality } \\
\hline \multirow[b]{2}{*}{$\mathbf{X}$} & \multicolumn{3}{|c|}{$\begin{array}{l}\text { Kolmogorov- } \\
\text { Smirnov }^{\mathbf{a}}\end{array}$} & \multicolumn{3}{|c|}{ Shapiro-Wilk } \\
\hline & $\begin{array}{c}\text { Stati } \\
\text { stic }\end{array}$ & df & Sig. & $\begin{array}{c}\text { Stati } \\
\text { stic }\end{array}$ & df & Sig. \\
\hline \begin{tabular}{|l|l} 
& Kepemilikan \\
Saham \\
Mayoritas \\
Institusional \\
dan \\
Kepemilikan \\
Saham \\
Manajerial \\
\end{tabular} & .223 & 10 & .174 & .864 & 10 & .085 \\
\hline $\begin{array}{l}\text { Kepemilikan } \\
\text { Saham } \\
\text { Mayoritas } \\
\text { Manajerial } \\
\text { dan } \\
\text { Kepemilikan } \\
\text { Saham } \\
\text { Minoritas } \\
\text { Institusional }\end{array}$ & .170 & 10 & $.200^{*}$ & 939 & 10 & .541 \\
\hline
\end{tabular}

Berdasarkan tabel 6. dijelaskan bahwa diperoleh nilai signifikansi untuk Kepemilikan Saham Mayoritas Institusional dan Kepemilikan Saham Manajerial sebesar 0.085, sedangkan nilai signifikansi Kepemilikan Saham Mayoritas Manajerial dan Kepemilikan Saham Minoritas Institusional sebesar 0.541.Karena nilai signifikansi lebih besar $\geq 0.05$, maka dapat disimpulkan bahwa data struktur kepemilikan berdistribusi normal

Uji Homogeneity

Tabel 7.

Uji Homogeneity

Test of Homogeneity of Variances Keputusan Pendanaan

\begin{tabular}{|c|c|c|c|}
\hline $\begin{array}{c}\text { Levene } \\
\text { Statistic }\end{array}$ & df1 & df2 & Sig. \\
\hline 1.013 & 1 & 18 & .328 \\
\hline
\end{tabular}

Sumber: Data Diolah SPSS

Berdasarkan tabel 7 dilihat nilai signifikan sebesar $0,328 \geq 0,05$, sehingga dapat disimpulkan bahwa data keputusan pendanaan berdasarkan jenis manipulasi (pengungkapan) memiliki varians yang sama (homogen).

\section{Uji Analysis of Variance ANOVA}

Tabel 8.

Uji Analysis of Variance ANOVA

\begin{tabular}{|l|r|r|r|c|c|}
\hline \multicolumn{7}{|c|}{ KNOVutusan Pendanaan } \\
\hline & $\begin{array}{c}\text { Sum of } \\
\text { Squares }\end{array}$ & Df & $\begin{array}{c}\text { Mean } \\
\text { Square }\end{array}$ & F & Sig. \\
\hline $\begin{array}{l}\text { Between } \\
\text { Groups }\end{array}$ & 92.450 & 1 & 92.450 & 24.436 & .000 \\
\hline $\begin{array}{l}\text { Within } \\
\text { Groups }\end{array}$ & 68.100 & 18 & 3.783 & & - \\
\hline Total & 160.550 & 19 & & & - \\
\hline
\end{tabular}

Sumber: Data Diolah SPSS

Berdasarkan table 8 yang dimana 1 merupakan d.f Between Groups, 18 merupakan d.f Within Groups dan 24,436 adalah nilai hitung $\mathrm{F}$ dengan probabilitas signifikan sebesar $0,000 \leq$ 0,05 yang artinya terdapat perbedaan yang signifikan terhadap jumlah keputusan pendanaan 
yang diakibatkan oleh 2jenis manipulasi (treatment) yang berbeda.

$\underline{\text { Karakteristik Partisipan Eksperimen }}$

Karakteristik partisipan dalam eksperimen ini melibatkan 10 (sepuluh) orang partisipan atau subjek. Adapun karakteristik partisipan eksperimen dapat dilihat pada tabel 9 berikut:

\section{Tabel 9}

Karakteristik Partisipan Eksperimen

\begin{tabular}{|c|c|c|c|}
\hline No. & Karakteristik & Frekuensi & \begin{tabular}{|c|} 
Persentase \\
$(\%)$
\end{tabular} \\
\hline 1. & $\begin{array}{l}\text { Jenis Kelamin: } \\
\text { a. Pria } \\
\text { b. Wanita }\end{array}$ & $\begin{array}{l}3 \\
7\end{array}$ & $\begin{array}{l}30 \% \\
70 \%\end{array}$ \\
\hline & tal Partisipan & 10 & $100 \%$ \\
\hline 2. & 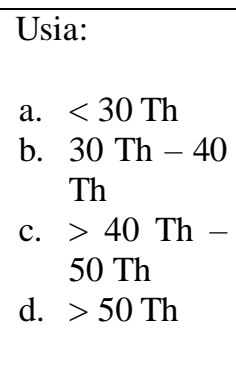 & $\begin{array}{l}1 \\
3 \\
6 \\
0\end{array}$ & $\begin{array}{l}10 \% \\
30 \% \\
60 \% \\
0 \%\end{array}$ \\
\hline & tal Partisipan & 10 & $100 \%$ \\
\hline 3. & $\begin{array}{l}\text { Pendidikan: } \\
\text { a. Strata } 1 \\
\text { b. Strata } 2 \\
\text { c. Strata } 3\end{array}$ & $\begin{array}{l}1 \\
7 \\
2\end{array}$ & $\begin{array}{l}10 \% \\
70 \% \\
20 \%\end{array}$ \\
\hline & tal Partisipan & 10 & $100 \%$ \\
\hline 4. & $\begin{array}{l}\text { Bidang } \\
\text { Pendidikan: } \\
\text { a. Ekonomi } \\
\text { b. Non } \\
\\
\text { Ekonomi } \\
\end{array}$ & 4 & $\begin{array}{l}60 \% \\
40 \%\end{array}$ \\
\hline \multicolumn{2}{|c|}{ Total Partisipan } & 10 & $100 \%$ \\
\hline
\end{tabular}

Tabel 9

Karakteristik Partisipan Eksperimen (Lanjutan)

\begin{tabular}{|c|c|c|c|}
\hline 6. & 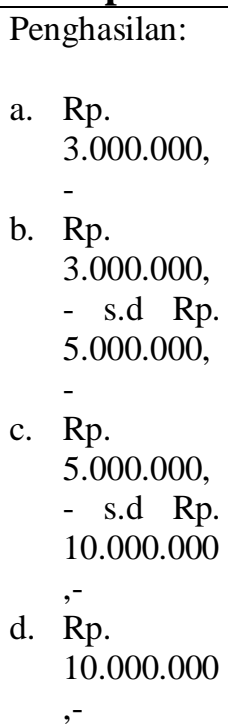 & 5 & $\begin{array}{l}30 \% \\
50 \% \\
20 \%\end{array}$ \\
\hline \multicolumn{2}{|c|}{ Total Partisipan } & 10 & $100 \%$ \\
\hline 7. & $\begin{array}{ll}\text { Institusi: } \\
\text { a. BUMN / } \\
\text { BUMD } \\
\text { b. Perusahaan } \\
\text { Swasta } \\
\text { Lainnya } \\
\text { c. Pendidikan } \\
\text { Tinggi } \\
\end{array}$ & 4 & $\begin{array}{l}40 \% \\
20 \%\end{array}$ \\
\hline \multicolumn{2}{|c|}{ Total Partisipan } & 10 & $100 \%$ \\
\hline
\end{tabular}

Sumber: Data Diolah

Dari penjelasan di atas maka dapat disimpulkan bahwa dari 10 partisipan ialah mayoritas berjenis kelamin wanita atau sekitar $70 \%$, dari segi usia mayoritas sekitar 40 hingga 50 tahun atau sekitar $60 \%$, dari segi pendidikan mayoritas berasal dari tamatan Strata 2 (S2) atau sekitar $70 \%$, dari segi bidang pendidikan mayoritas berasal dari bidang ekonomi atau sekitar $60 \%$, dari segi penghasilan setiap bulannya mayoritas antara Rp. 5.000.000,hingga Rp. 10.000.000,- atau sekitar 50\%, dan dari segi asal institusi mayoritas berasal dari BUMN / BUMD dan Pendidikan Tinggi sekitar $40 \%$. 
Analisis Comletely Randomized (Repeated Measures $t$ Test)

Tabel 10

Paired Sample Statistics

\begin{tabular}{|c|c|c|c|c|c|}
\hline & & Mean & $\mathbf{N}$ & $\begin{array}{l}\text { Std. } \\
\text { Devi } \\
\text { ation }\end{array}$ & $\begin{array}{l}\text { Std. } \\
\text { Error } \\
\text { Mean }\end{array}$ \\
\hline $\begin{array}{l}\text { Pair } \\
1\end{array}$ & $\begin{array}{l}\text { Kepemilika } \\
\mathrm{n} \quad \text { Saham } \\
\text { Mayoritas } \\
\text { Instutisional } \\
\text { dan } \\
\text { Minoritas } \\
\text { Manajerial }\end{array}$ & 9.00 & $\begin{array}{l}1 \\
0\end{array}$ & $\begin{array}{c}2.16 \\
0\end{array}$ & .683 \\
\hline & $\begin{array}{l}\text { Kepemilika } \\
\mathrm{n} \quad \text { Saham } \\
\text { Mayoritas } \\
\text { Manajerial } \\
\text { dan } \\
\text { Minoritas } \\
\text { Instutisional }\end{array}$ & 4.70 & $\begin{array}{l}1 \\
0\end{array}$ & $\begin{array}{c}1.70 \\
3\end{array}$ & .539 \\
\hline
\end{tabular}

Sumber: Data Diolah SPSS

Pada tabel 10 paired sample statistics menunjukkan ringkasan dari rata-rata dan standar deviasi dari kedua perlakuan. Untuk kepemilikan saham mayoritas institusional dan minoritas manajerial mempunyai nilai rata-rata (mean) 9,00 dari 10 data partisipan. Sebaran data (Std. Deviation) yang diperoleh adalah 2,160 dengan standar error 0,683. Data struktur kepemilikan mayoritas kepemilikan manajerial dan minoritas institusional mempunyai nilai ratarata (mean) 4,70 dari 10 data partisipan. Sebaran data (Std. Deviation) yang diperoleh 1,703 dengan standar error 0,539. Hal ini menunjukkan data struktur kepemilikan mayoritas kepemilikan instutisional dan minoritas kepemilikan manajerial pada data lebih tinggi dari data struktur kepemilikan mayoritas kepemilikan manajerial dan minoritas kepemilikan institusional.Namun rentang sebaran data struktur kepemilikan mayoritas kepemilikan institusional dan minoritas kepemilikan manajerial menjadi semakin lebar dengan standar error yang semakin tinggi.
Tabel 11

Paired Sample Test

\begin{tabular}{|c|c|c|c|c|c|c|c|c|}
\hline & \multicolumn{5}{|c|}{ Paired Differences } & & \multirow{4}{*}{ df } & \\
\hline & \multirow{3}{*}{\multicolumn{2}{|c|}{\begin{tabular}{|c|c} 
& Std. \\
Deviat \\
Mean & ion
\end{tabular}}} & \multirow{3}{*}{$\begin{array}{l}\text { Std. } \\
\text { Error } \\
\text { Mean }\end{array}$} & \multicolumn{2}{|c|}{\begin{tabular}{|c|}
$95 \%$ \\
Confiden \\
ce \\
Interval \\
of the \\
Diference
\end{tabular}} & & & $\begin{array}{c}(2- \\
\text { ailed } \\
)\end{array}$ \\
\hline & & & & Low & Upp & & & \\
\hline & & & & er & er & & & \\
\hline $\begin{array}{|lr|}\text { Kepemilik } \\
\text { an } & \text { Saham } \\
\text { Mayoritas } \\
\text { Instutision } \\
\text { al } & \text { dan } \\
\text { Minoritas } \\
\text { Manajerial }\end{array}$ & & & & & & & & \\
\hline $\begin{array}{l}\text { Kepemilik } \\
\text { an Saham } \\
\text { Mayoritas } \\
\text { Manajerial } \\
\text { dan } \\
\text { Minoritas } \\
\text { Instutision } \\
\text { al }\end{array}$ & 4.300 & 2.584 & . 817. & 2.451 & 6.149 & 62 & & 0.00 \\
\hline
\end{tabular}

Sumber: Data Diolah SPSS

Berdasarkan tabel 11 dapat dilihat bahwa nilai t hitung adalah sebesar 5,262 dengan sig 0,001 . Karena sig $<0,05$ maka hipotesis nol ditolak dan hipotesis alternatif diterima yang berarti bahwa ada perbedaan nilai terhadap mayoritas kepemilikan institusional dan minoritas manajerial dengan mayoritas kepemilikan manajerial dan minoritas kepemilikan institusional.

\section{$\underline{\text { Pembahasan }}$}

Berdasarkan tabel 10 dapat disimpulkan bahwa tidak terdapat hubunganyang berbeda antar manipulasi atau sel (sepadan). Berdasarkan analisis di atas bahwa data struktur kepemilikan berdistribusi normal. Hasil uji homogeneity pada dapat disimpulkan bahwa keputusan pendanaan berdasarkan jenis manipulasi (pengungkapan) memiliki varians yang sama (homogen). Kemudian hasil uji ANOVA dapat disimpulkan bahwa terdapat perbedaan signifikan terhadap jumlah keputusan 
pendanaan yang diakibatkan oleh dua jenis manipulasi (treatment) yang berbeda.

Hipotesisi diuji dengan menggunakan analisis Repeated Measures $t$ Test dengan variabel independen secara berulang ${ }^{13}$. Berdasarkan hasil uji analisis Comletely Randomized (Repeated Measures $t$ Test) dimana hasil menunjukkan bahwa perlakuan yang pertama (struktur kepemilikan mayoritas institusional dan minoritas manajerial) memiliki hasil tertinggi dibandingkan dengan perlakuan yang kedua (struktur kepemilikan mayoritas manajerial dan minoritas institusional). Penelitian yang dilakukan memberikan pengetahuan mengenai dampak struktur kepemilikan terhadap keputusan pendanaan dengan menggunakan perlakuan (treatment) secara berulang-ulang pada data struktur kepemilikan yang dimana perlakuan pertama terdapat struktur kepemilikan dengan mayoritas institusional dan minoritas manajerial sedangkan perlakuan kedua terdapat struktur kepemilikan dengan mayoritas manajerial dan minoritas institusional.Sementara hasil dapat disimpulkan bahwa hipotesis nol ditolak dan hipotesis alternatif diterima.

Melihat dari kedua perlakuan yang diberikan kepada partisipan dapat dikatakan bahwa partisipan akan melakukan keputusan pendanaan ketika diberikan perlakuan yang pertama yaitu dengan struktur kepemilikan mayoritas institusional dan struktur kepemilikan manajerial. Penelitian ini menunjukkan bahwa hipotesis alternatif yang mengatakan bahwa struktur kepemilikan berdampak pada keputusan pendanaan.

\section{KESIMPULAN}

Berdasarkan fenomena,rumusan masalah, hipotesis, metode penelitian yang digunakan, dan hasil penelitian maka peneliti menarik kesimpulan secara empiris bahwa terdapat kovarasi antara struktur kepemilikan dengan keputusan pendanaan pada perusahaan manufaktur. Yang dimana artinya pengungkapan struktur kepemilikan berdampak terhadap keputusan pendanaan pada perusahaan manufaktur.

\section{SARAN}

1. Untuk perusahaan diharapkan dapat mempertahankan peningkatan struktur kepemilikan sehingga dapat menjadi bahan pertimbangan bagi investor dalam memberikan keputusan pendanaan pada perusahaan.

2. Untuk peneliti berikutnya yang akan mengambil judul yang sama, disarankan untuk melakukan pemadanan antar anggota partisipan pada waktu dan tempat yang berbeda.

3. Dalam memilih partisipan agar dapat memilih partisipan yang relative homogen. Selain itu diharapkan untuk dapat memperluas penelitian ini dengan meneliti lebih lanjut faktor lain yang bisa mempengaruhi keputusan pendanaan pada perusahaan manufaktu

\section{DAFTAR PUSTAKA}

Ayulestari P, Kirmizi, Azhar A A. Pengaruh Keputusan Investasi, Keputusan Pendanaan, Dan Tingkat Suku Bungan Terhadap Nilai Perusahaan Pada Perusahaan Otomotif Yang Terdaftar Di Bursa Efek Indonesia. 2012:1-10.

Banding, M. P. \& Mayangsari, Sekar (2017). The Impact of Financial and NonFinancial Information Disclosure to Donation Decision in NonProfit Organization by Individual Donor (A TrueExperiment Research).1-11

Ghozali I. Desain Penelitian Eksperimental. Teori, Konsep dan Analsiis dengan SPSS 16. 1 ed. Semarang: Badan Penerbit Universitas Diponegoro; 2008.

Haruman T. National Conference Onmanagement Research. Pengaruh Strukt Kepemilikan Terhadap Keputusan Pendanaan. 2008.

Jensen MC, Meckling WH. Theory of The Firm. Manag Behav Agency Cost Ownersh Struct. 1976:305-360.

Nahartyo E, Utami I. Panduan Praktis Riset Eksperimen. pertama. (Sarwiji B, ed.). Jakarta: PT. indeks; 2016.

Nahartyo E, Utami I. Paduan Praktis Riset Eksperimen. 1 ed. jakarta: Indeks; 2016.

Nur'Aeni D. Pengaruh struktur kepemilikan saham terhadap kinerja perusahaan. Pengaruh Strukt Kepemilikan Saham 
Terhadap Kinerja Perusah. 2010.

Sabrinna AI. No Title. Pengaruh Corp Gov dan Strukt Kepemilikan Terhadap Kinerja Perusah. 2010.

Utami DI, Nahartyo E. Panduan Praktis Riset Eksperimen (cetakan I). 2016.

Uma S. No Title. In: Metode Peneitian Bisnis. Salemba Em. Jakarta; 2006.

Wicaksono A. Struktur Kepemilikan Pengungkapan dan Corporate Governance. Suatu Anal Fak Ekon Jur Akunt. 2000.

Wiranata YA, Nugrahanti YW. Pengaruh Struktur Kepemilikan Terhadap Profitabilitas Perusahaan Manufaktur di Indonesia. 2013;15(1):15-26. doi:10.9744/jak.15.1.15-26. 